\title{
Sovereign Debt Restructuring: A Modest Proposal
}

\author{
Colin Ellis ${ }^{1}$ \\ ${ }^{1}$ Visiting Research Fellow, University of Birmingham, Birmingham, UK \\ Correspondence: Colin Ellis, University of Birmingham, Edgbaston, Birmingham, B15 2TT, United Kingdom.
}

Received: January 28, 2021; Accepted: February 16, 2021; Published: March 8, 2021

\begin{abstract}
Many sovereigns, including weaker credits, have taken on substantial debt during the COVID-19 pandemic. This raises the prospect of future defaults and sovereign restructurings, which will be informed by debt-sustainability analysis. But when analyzing notable recent sovereign defaults, we find a pattern of serially correlated errors: the analysis at the time of the restructuring is too optimistic about future sovereign debt dynamics. In light of this, I propose that future sustainability analysis should be based on more pessimistic expectations. In turn, this implies that sovereign creditors should face larger losses in future restructurings.
\end{abstract}

Keywords: sovereign default, debt-sustainability analysis, forecast evaluation

\section{Introduction}

With the COVID-19 pandemic still raging in many countries, governments around the world have borrowed significant sums both to respond to the health crisis and to support companies and employees in those parts of the economy most affected by shutdowns in activity and other aspects of the pandemic. This has resulted in a significant increase in public debt-GDP ratios. In addition, in many instances countries came into the pandemic having failed to reduce the increases in debt-GDP resulting from the global financial crisis (GFC).

While advanced economies have been able to access financial markets to issue debt, supported by central bank actions, many emerging economies do not enjoy the same degree of access. This led to measures such as the Debt Service Suspension Initiative (DSSI) led by the G20, and taken up by the World Bank and International Monetary Fund (IMF). The DSSI aimed to give emerging economies some breathing space, letting them use their financial resources to fight the pandemic rather than service (official sector) debt obligations.

But the pandemic and initiatives such as the DSSI have also thrown into sharp relief the fact that many emerging economies still face substantial challenges to ensure debt sustainability. Formally, debts are ultimately sustainable if defaults are avoided; but the ex ante credit risks associated with those defaults can wax and wane as economic and financial conditions deteriorate and improve. Rating agencies provide one assessment of these ex ante credit risks: as of January 2020, Moody's rates three-quarters of the sovereign credits it covers in the Sub-Saharan Africa (SSA) region at B1 or below (Figure 1). Obligations rated at single B are "considered speculative and are subject to high credit risk", with ratings in the Caa category "judged to be speculative of poor standing and are subject to very high credit risk" (Moodys, 2021).

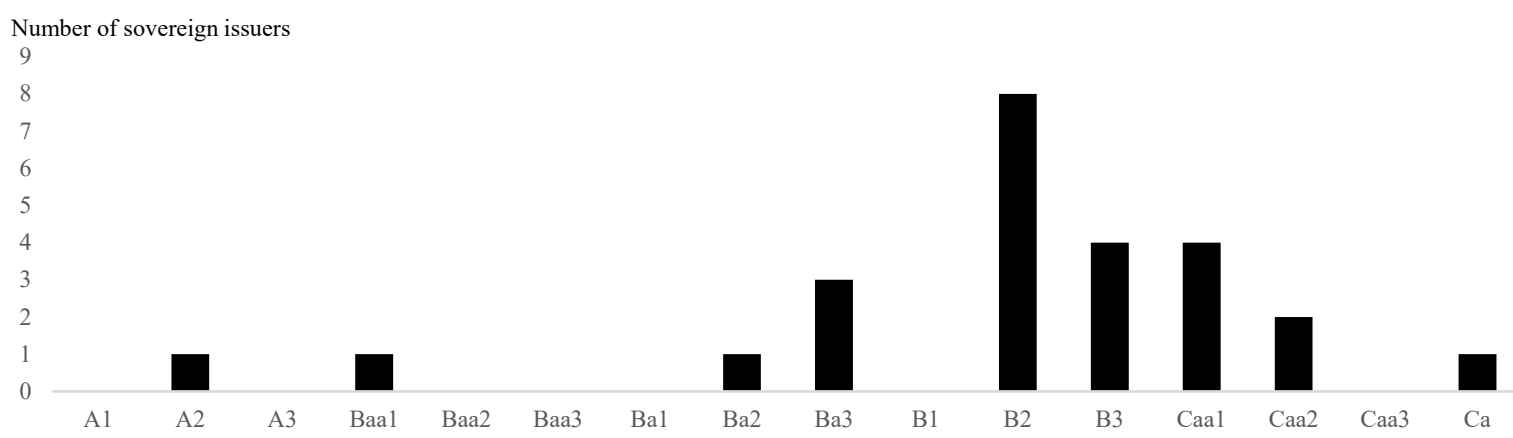

Figure 1. Sovereign credit rating distribution in Sub-Saharan Africa

Source: Moody's. 
This high proportion of low-rated sovereigns is entirely consistent with those countries not having the financial resources to both fight the pandemic and meet their debt obligations, which was why the DSSI was proposed. However, a simple suspension of (official sector) interest payments is highly unlikely to reduce the credit risks these sovereigns pose; ultimately, many of them are likely to default over the next five years, based on the past performance of ratings (Figure 2).

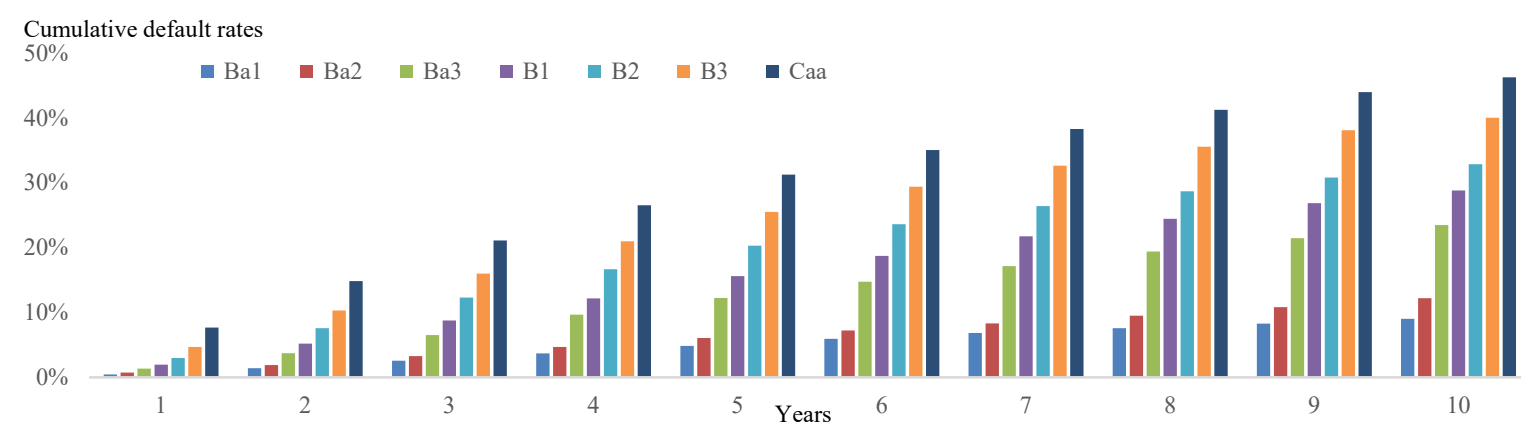

Figure 2. Cumulative default rates for different rating categories

Source: Moody's.

This raises the prospect of a significant number of sovereign defaults occurring over the medium term, defined here as the next five years or so. In light of this outlook, the next section of this paper reviews the current state of sovereign default processes, noting the issues and challenges that are currently prevalent. The subsequent section focuses on the data, highlighting some important empirical evidence from past default events, finding and overoptimistic bias in post-default assessments of future debt levels. Finally, in light of this empirical evidence the paper makes a simple proposal to improve the effectiveness of future sovereign debt restructurings, and concludes.

\section{Sovereign Debt Restructurings: Some Current Issues}

Sovereign defaults are painful. Whatever form they take - for instance missed interest or principal payments that are easy to observe, or distressed exchanges where governments swap existing obligations for new ones with lower financial values, or so-called 'restructurings' where the same effect is achieved - the impact of a default is typically deep and pervasive. Even when a default has been long-expected, or is consensually agreed with creditors, its effects are normally felt through the domestic economy of the defaulter, and can impact private creditors' willingness to lend to that country in the future. For instance, Sturzenegger and Zettelmeyer (2006) find that sovereign borrowing costs are typically higher by an estimated 50-100 basis points for countries after they default, with this effect persisting for several years. Spillover effects to other countries can also occur, reflecting a variety of transmission channels such as broad-based re-assessment of risks by creditors resulting in sovereigns' reduced access to funds, or direct economic, trade and financial linkages between the defaulting country and other nations.

Given the traumatic impact of these defaults, in the past some countries have refused to acknowledge rising credit risks until the default is inevitable. But even when a default is odds-on, the process and nature of sovereign defaults can vary significantly.

\subsection{Background on The Paris Club}

There are common frameworks for these default processes. The Paris Club, in particular, represents sovereigns that act as official sector creditors to other countries. Once a defaulting country has acknowledged its debt is unsustainable, for instance by agreeing a post-default financial support program with the IMF, it can meet with the Paris Club if it has a financing gap that can be closed with a debt rescheduling or restructuring.

Some broad principles underlie Paris Club discussions. These include solidarity and consensus: all Paris Club members must act as a group, with decisions accepted by all members. Members share information with each other, and decisions can be tailored to individual debtor countries' circumstances.

Importantly, the Paris Club insists on two key requirements. First, conditionality: discussions about debt restructuring only take place when debt relief is required and the debtor country is enacting reforms to address its debt challenges. And second, any restructuring agreements with non-Paris Club creditors will not provide for more favourable terms than agreed by the Paris Club. 
The flexibility offered by tailoring restructuring defaults to individual debtor countries' circumstances allows for considerable variation in the treatment of defaults: yet at the same time this tailoring of agreements can make it hard to predict what the outcome of debt discussions will be. It is also reliant on high quality and accurate debt sustainability analysis (DSA); the Paris Club typically relies on the IMF for this. An accurate DSA is essential in order to accurately gauge how much debt relief is required; or in other words, how much the value of debt must be reduced for the debtor country to successfully manage its post-default obligations. This link to the IMF's DSA is why Paris Club agreements normally coincide with IMF support programmes.

The aim of Paris Club agreements is to achieve a delicate balance. On the one hand, any agreement needs to make debt sustainable for the debtor country; achieving this will both boost private capital flows into the country, supporting economic restructuring efforts, and provide some (limited) fiscal space for the government to respond to ongoing developments and future shocks. On the other hand, the Paris Club is always conscious of moral hazard; it does not want restructuring exercises to be too easy for sovereign borrowers, as that would create incentive problems.

\subsection{Current Issues Around Sovereign Restructurings}

Even prior to the advent of DSSI, sovereign debt discussions faced several issues.

First, there have been significant concerns about data accuracy in recent years. In several instances, it has been challenging both for the IMF and the Paris Club, let alone private creditors, to get accurate information about the outstanding debts of a defaulting sovereign. In part, this has reflected the growing influence of China, particularly in lending funds to Africa. Often, these borrowings have been through Chinese state-run banks or other entities, rather than from the Chinese government directly. But a lack of transparency about these obligations - and critically, concerns that they would not be treated equally alongside other debtor obligations in any restructuring - has impeded trust and restructuring processes. However, a lack of Chinese transparency is not the only data challenge facing creditors: for instance, information on obligations of state-owned enterprises (SOEs), which are often included in restructuring discussions, can also be difficult to find.

Second, there has been considerable discussion about contingent convertible debt and other new instruments for sovereigns. Following the 2007/8 GFC, many countries introduced new forms of bank debt that would automatically be written down in the event of bank distress or failure: creditors would suffer losses automatically following some trigger event. These contingent convertibles (or CoCos) have been issued by several banks, although market liquidity has not always been very deep.

In principle, similar instruments could be issued for sovereigns: Barkbu et al (2012) and Brooke et al (2013) offer some discussion here. The French Aid Agency previously used maturity extension contingent debt for some African countries in 2009, but other forms of contingent debt could also be issued, providing write-down triggers could be identified and agreed. These instruments would provide immediate debt relief for sovereigns once the trigger was struck.

Sovereign CoCos are yet to emerge as a new asset class. One potential avenue is for sovereigns to issue debt where they can contractually skip interest payments under certain conditions: this would essentially be building on 'grace periods' that are already often in contractual obligations. Related to CoCos, these securities would then be impaired - but not technically be in default - when those conditions were met. This would provide limited debt relief, similar to the DSSI proposal seen last year.

Other new types of instruments have also been proposed. One idea, originally proposed by Shiller (1998) is GDPlinked bonds. Similar to inflation-linked bonds issued in the UK, the US and elsewhere, these bonds would pay variable interest linked to economic performance; and in the case of recessions, could even reduce the nominal debt values outstanding. Research suggests these GDP-linked bonds could boost welfare and potentially sustainable debt levels (Barr et al, 2014); but, as yet, the market for them remains unproven.

More generally, precise contractual terms have also become more of a focus in sovereign bond documentation over the past decade. For instance, following the experience of Greece in particular in 2012, collective action clauses (CACs) are more widespread: these allow a specified majority of bondholders to agree a restructuring that is legally binding on all bondholders. At the same time, cross-default clauses, which would cause sovereigns to be in default on other obligations if they restructured only part of their debt, were cited as one reason more countries did not participate in the DSSI last year.

One notable improvement in recent years has been better coordination among private sector creditors of sovereigns. Previously, the likes of the London Club have represented commercial creditors (largely banks), although there were many different such groups. However, more recently the Institute for International Finance 
(IIF) has stepped in to help facilitate discussions among private sector creditors, and between those creditors and other entities such as the Paris Club. While some private creditors such as vulture funds remain aloof from these offers, the IIF has provided more of a unified voice for private creditors.

\section{Evaluating the accuracy of debt forecasts}

As noted above, one critical aspect of any sovereign restructuring is the DSA. This is typically provided by the IMF for official sector creditors (the Paris Club), but many private sector institutions conduct their own analysis. An accurate DSA is critical to ensure that the sovereign default achieves the desired objective of making its debt sustainable again. In order words, if the default does not reduce the sovereign's debt obligations enough, it may be back in default again very soon.

This is not an academic issue. For instance, past research has found that, when countries default via a distressed exchange, fully $37 \%$ of those sovereigns then defaulted a second time (Moody's, 2012). Put simply, just under half the time the initial default event did not restore debt sustainability sufficiently to avoid another default. This is obviously one reason why sovereign credit ratings may take some time to improve following default events.

This suggests that, in these instances, any DSA associated with the initial default was over-optimistic in its assessment of how much the default would restore debt sustainability and reduce credit risks. One way to test this is to look at significant past defaults, and assess whether the forecasts for debt metric made at the time of the default were accurate or not.

Table 1. Sample of major sovereign default events

\begin{tabular}{lll}
\hline Country & Month(s) of default & Nature of default \\
\hline Greece & March \& December 2012 & Separate distressed exchanges \\
Argentina & July 2014 & Missed payment \\
Ukraine & November 2015 & Missed payment \& distressed exchange \\
Mozambique & April 2016, February 2017 & Separate distressed exchanges, missed payment also \\
Venezuela & November 2017 (initially) & Missed payment \\
Barbados & June 2018 & Missed payment \& distressed exchange \\
\hline
\end{tabular}

Source: Moody's.

We focus here on some of the more sizeable and notable defaults over the past decade, that affected a broad range of creditors. In particular, we consider: Greece (defaulted twice in 2012); Argentina (2014); Ukraine (2015); Mozambique (2016 \& 2017); Venezuela (2017 initially); and Barbados (2018). These default events are summarised in Table 1. It is important to note that each episode here is treated as one (or at most two) sovereign defaults; this is standard in the literature, rather than counting each individual bond or issue that is affected at the same time. It is important to note that the instances of default above represent a small sample on which to draw inference; this is directly reflected in the 'modest proposal' that will ensue from the analysis. However, even small sample sizes can offer early indications of potential issues, particularly if the results are repeated and directionally consistent.

As noted earlier, the IMF is often the primary source of DSA in instances of sovereign default. This is true not just for defaults on official sector obligations but also for defaults suffered by private creditors; a common consequence of the latter is that countries require IMF funding programmes because market access to private capital is lost. Unfortunately, the full DSAs covering different restructuring options are not always publicly available. But assuming consistency across IMF analysis - a simple alternative is to examine the IMF's published debt forecasts immediately after the defaults occurred.

Twice a year, in the World Economic Outlook (WEO), the IMF publishes economic forecasts for the global economy and (most of) the individual countries within it. While these forecasts typically only cover headline data, one widely available data series is an individual country's ratio of general government debt to GDP. By using the real-time WEO forecast immediately after the default events shown in Table 1, we can then examine whether the IMF was over- or under-optimistic in its assessment of how debt ratios would evolve for these countries. To be clear, the debt-GDP ratio is not a sufficient statistic in and of itself for gauging sovereign debt sustainability; but 
it is certainly relevant, and can act as a summary indicator of whether the IMF forecasts were accurate or not. We examine each of then countries shown in Table 1 in turn.

\subsection{Greece's 2012 Defaults}

One of the most prominent defaults of the past decade was Greece in 2012. This was very notable as sovereign defaults since the Second World War had typically been limited to emerging markets, not advanced economies such as Greece. In the end, the Greek sovereign defaulted twice within the same calendar year in 2012.

Concerns about the sustainability of Greek sovereign debt were thrown into sharp relief in late 2009, when the new government announced that past deficits and debt were significantly higher than previously thought. Further negative economic developments and upward revisions to deficits weakened investor confidence, and Greece lost market access in May 2010. Despite substantial official sector funding from the IMF and Greece's European partners, the fiscal situation continued to deteriorate. In March 2012, the Greek government restructured its debt having retroactively inserted CACs via national legislation. Subsequently, the Greek debt management office then conducted a buy-back of debt on the secondary market in December 2012. This had the effect of crystallizing credit losses for bondholders, and as such represented another distressed exchange with substantial losses against par values.

The role of the IMF in the Greek debt restructurings was both controversial and critical. In particular, several of Greece's European partners insisted that the IMF lead the technical analysis around debt sustainability; the IMF's expertise was widely recognised in this area.

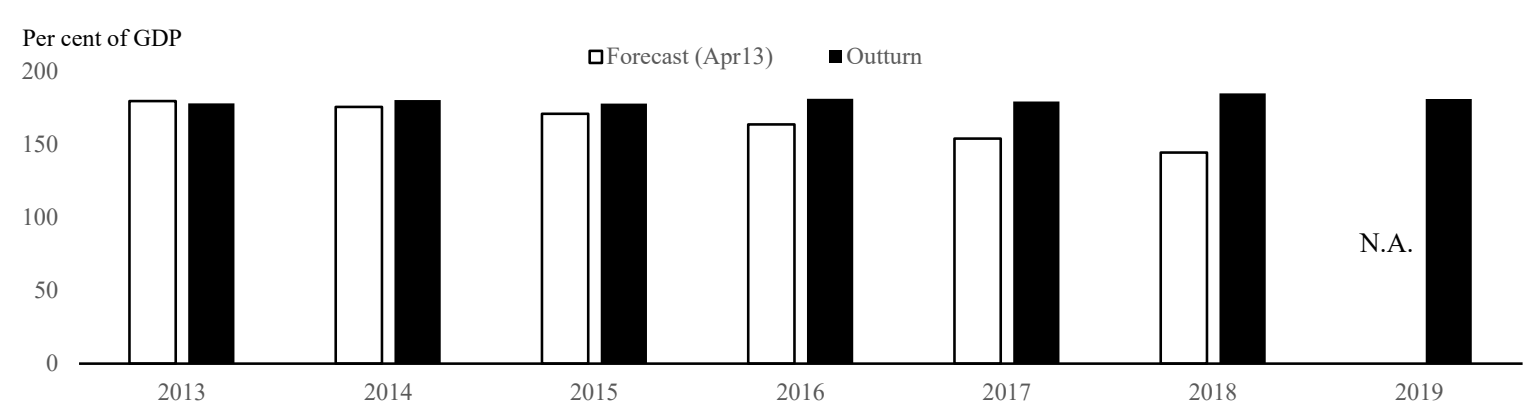

Figure 3. Greek government debt-GDP forecast and outturns

Source: IMF and author's calculations. "N.A." denotes not available.

However, the IMF's forecast turned out to be too optimistic. The IMF's first global forecast exercise following the December 2012 default was published in April 2013: but the forecast was too optimistic for the Greek debt-GDP ratio (Figure 3). The 2013 forecast only ran for the subsequent five years to 2018; but if we compare the end-point of that forecast with what the debt-GDP ratio actually was in 2018, the gap between the forecast and outturn was 40 percentage points. Even given the substantial uncertainties facing Greece in the aftermath of its default, that is a very large forecast error. The IMF's analysts of Greek debt was obviously too optimistic in this instance.

\subsection{Argentina's 2014 Default}

The second default we will examine here centres on Argentina's missed payment in July 2014.

A 2012 ruling by the US Second Circuit Court of Appeals decreed that Argentina was required to meet the pari passu clause in its bond contracts, and could not discriminate between debt that was not previously restructured in its 2005 and 2010 defaults. The Court also ruled that litigating bondholders should be paid in full at the same time as any payments were made to holders of Argentina's restructured debt.

By the end of July 2014, holders of the restructured 2005 and 2010 bonds had not received their interest payment with the 30-day grace period following the scheduled 30 June payment date: this therefore represented another default. Although Argentina had deposited the funds into a trustee account, the paying agent was subject to an injunction linked to the 2012 ruling, and so could not legally transfer the funds to bondholders. There were further missed payments subsequent to this default event. 
Once again we can compare the IMF's assessment of debt dynamics at the time of the default with what actually occurred. The first global forecast published after the default dates from October 2014, where the IMF expected Argentina's debt-GDP ratio to rise steadily over subsequent years, but remain around $60 \%$ by 2019 .

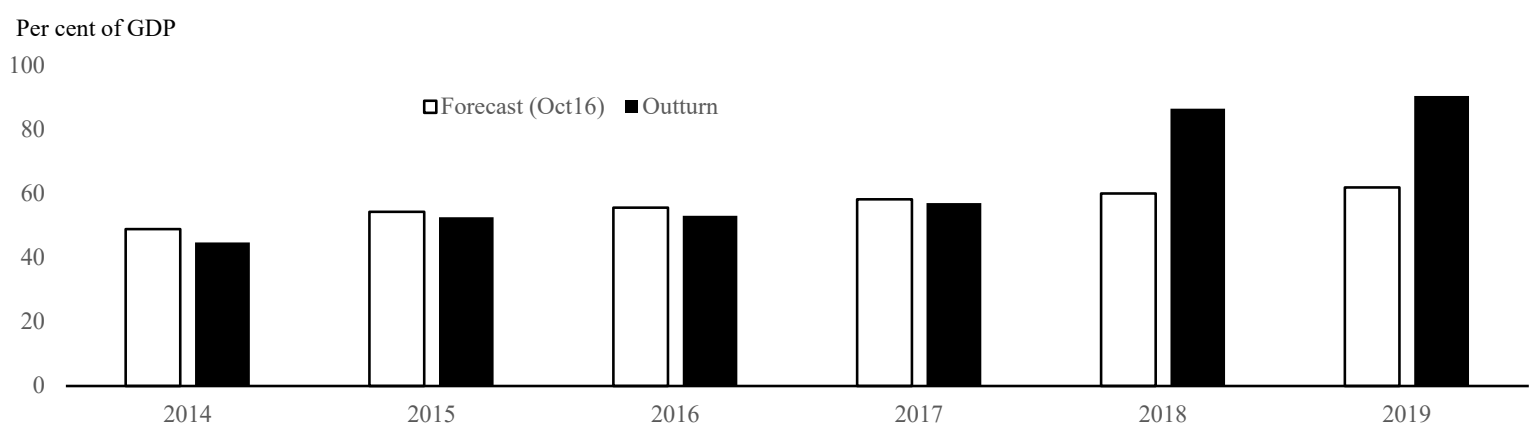

Figure 4. Argentinian government debt-GDP forecast and outturns

Source: IMF and author's calculations.

In the years immediately following the default, the forecast was reasonably accurate. But there was a clear divergence between forecast and outturns in 2018. By the following year, the gap between the forecast and outturn was over 28 ppts of GDP, in no small part reflecting the renewed financial issues and challenges that Argentina faced given its shrinking economy. While forecasting medium-term developments is intrinsically difficult, it is nonetheless a critical element of the DSA that the IMF (and others) conduct: and here too, as with Greece, the IMF's assumptions were clearly over-optimistic.

\subsection{Ukraine's 2015 Defaults Amidst Armed Conflict}

Another major European default in the past decade was that of Ukraine in 2015. Ukraine's economic and financial situation deteriorated dramatically due to the civil war in Ukraine that erupted following the popular uprising against President Yanukovych in 2014, and the subsequent annexation of Crimea by Russia under President Putin. With the Ukrainian currency allowed to float, the hryvnia depreciated substantially, leading to a sharp rise in inflation. Faced with severe economic dislocation, the government negotiated a comprehensive support package with the IMF and others in February 2015.

As part of that package, the IMF required Ukraine to negotiate a debt restructuring with creditors. Most were amenable to this process - the key holdout being Russia - and settlement on the restructuring was completed on 12 November, following a missed payment under the then-existing obligations on 23 September (after the 10 day grace period). Intriguingly, the restructured debt included GDP warrants on the new bonds, which would provide an equity-like return for bondholders if the economy performed strongly.

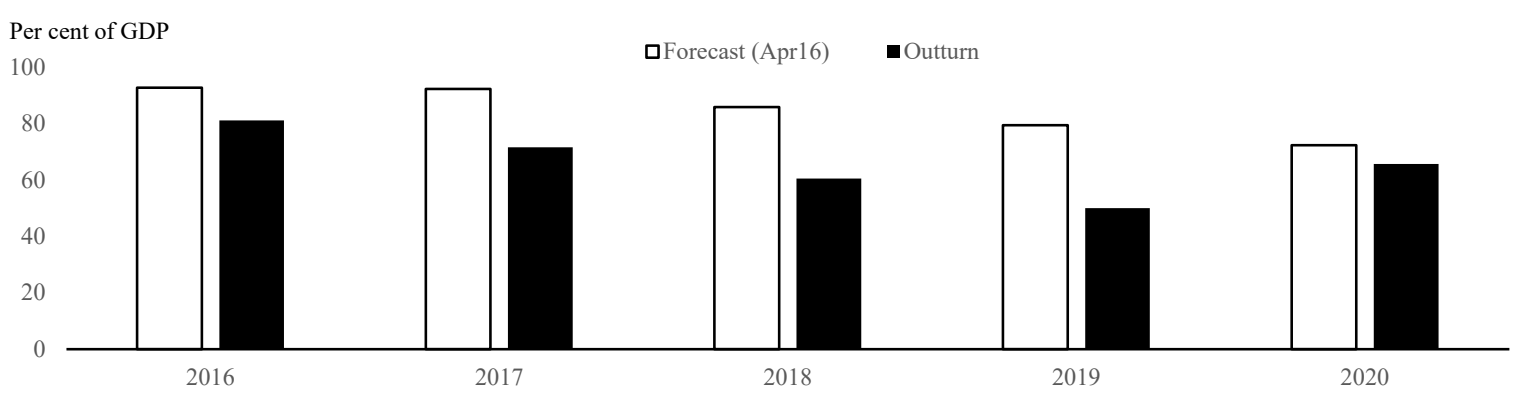

Figure 5. Ukrainian government debt-GDP forecast and outturns

Source: IMF and author's calculations. 2020 outturn reflects IMF's latest forecast.

Evidence from the Ukrainian episode is more complex, but still instructive. At first glance, Figure 5 seems to suggest that the IMF's immediate post-default forecast (in April 2016) was more accurate than the previous two 
examples and - if anything - too pessimistic. Public debt-GDP fell rapidly in Ukraine between 2016 and 2019, before rising last year.

However, this simple narrative misses the important role that data revisions have played. In particular, the starting debt-GDP ratio following the default turned out to be significantly lower in 2016 than originally anticipated. And while medium-term forecasts are always challenging, near-term forecast errors such as these often reflect data errors in official statistics. This was exactly the case here: as better data became available, the initial 2016 estimate of public debt was subsequently revised down by $8.5 \%$, while at the same time nominal GDP was revised up by $4.6 \%$. Overall, the Ukrainian debt-GDP ratio was revised down by over 11 percentage points.

Given the conflict Ukraine was embroiled in, these data revisions are entirely understandable: but at the same time they also more than account for the apparent 'accuracy' in the IMF's 2016 forecasts. In fact, when we adjust the forecast error in 2020 for the gap in 2016 reflecting data revisions, the IMF forecast was again too optimistic, by around 5 ppts of GDP. Admittedly, this is a smaller magnitude of forecast error than for other countries. But relying on data revisions to enable forecast accuracy does not seem like a sensible strategy for DSA; and as such, the underlying story here is again of the IMF being (somewhat) over-optimistic in its forecast of debt dynamics.

\subsection{Mozambique: Hidden debt a Key Issue}

Mozambique is another notable instance of sovereign distress, and is another recurring defaulter from the past decade. The country was already under considerable external pressure at the end of 2015, with foreign exchange reserves falling rapidly as the exchange rate fell substantially. In addition, the revelation of the government's management of previously unknown debt contracted by state-owned enterprises (SOEs) shook investor confidence. While the government stepped in to help the government service its debt in late 2015, pressures on the sovereign were not contained and Mozambique defaulted in April 2016 via a distressed exchange of notes issues by one of the SoEs. Subsequent to this, further hidden borrowing was disclosed, causing international donors including the IMF to suspend support. Mozambique announced its intention to restructure its debt in October 2016, and subsequently missed a 15-day grace period for a payment in 2017 . While the government has made progress in restructuring its own debts, defaults on government-guaranteed loans involving SoEs remain unresolved.

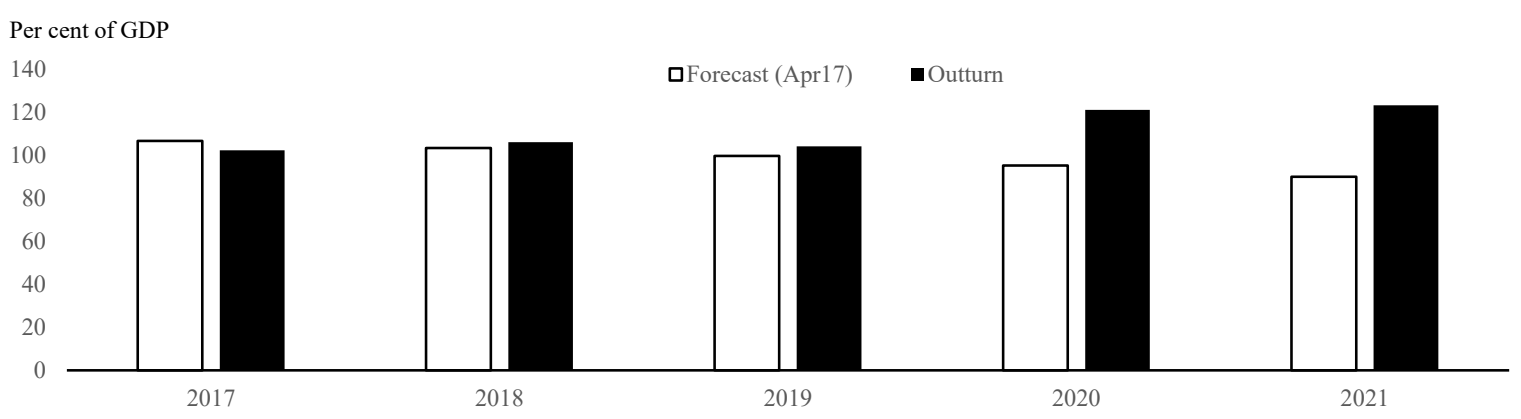

Figure 6. Mozambique government debt-GDP forecast and outturns

Source: IMF and author's calculations. 2020 outturn reflects IMF's latest forecast.

The IMF forecast immediately after this second default in 2017 was for debt-GDP to decline gradually over the course of the next three years. However - as has already been seen for other countries - once again these forecasts proved too optimistic. By 2020, the forecast error on the debt-GDP ratio was over 25 percentage points (Figure 6).

\subsection{Venezuela: A Serial Defaulter}

Venezuela's government default in 2017 was not particularly surprising for market participants, but still marked a significant failure of policy for a country that had the world's largest proven oil reserves at the time. In part, this reflected the severe credit challenges facing the country including a large external funding gap and shortages of foreign exchange, macroeconomic imbalances, poor governance and data, and elevated social tensions.

Substantial government liquidity pressures resulted in a series of missed payments on government debt, and the debts of the major SOE that managed Venezuela's oil production. The government formally first defaulted on 12 November 2017, after the expiry of the grace period for interest payments due on its bonds. The SOE had previously defaulted 10 days earlier. 
Subsequently, the sovereign missed interest and principal payments on many other bonds, including payments due on 15 August 2018, 1 December 2018, and at least 12 subsequent payment dates. Any resolution of these unpaid obligations seems unlikely in the near term.

Venezuela is different from many other defaulting sovereigns in that it was not the recipient of an IMF program. But nonetheless it is still instructive to consider how the IMF viewed debt dynamics at the time of default, and compare this with the situation for other countries.

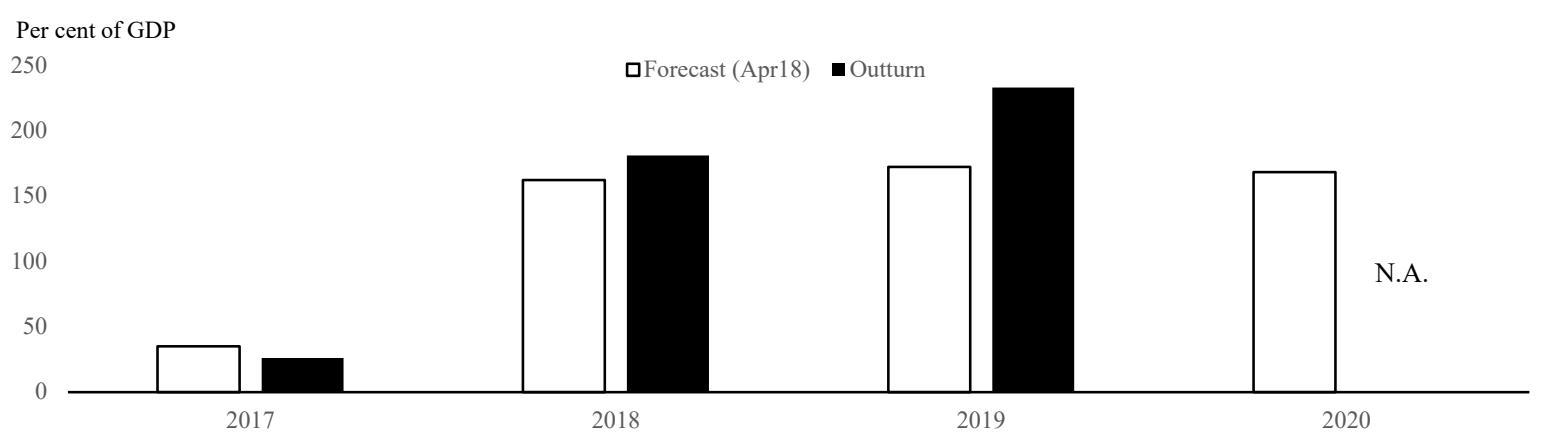

Figure 7. Venezuelan government debt-GDP forecast and outturns

Source: IMF and author's calculations. "N.A." denotes not available.

At the time of the default, Venezuela did not actually have a particularly high debt-GDP ratio: it was comfortably under $50 \%$ of GDP for the calendar year of 2017. Thereafter, however, shut out from global financial markets and suffering a significant collapse in its currency that amplified its foreign-currency borrowings, debt-GDP soared in subsequent years. In its April 2018 forecast, shortly after the default, the IMF forecast that debt-GDP would peak at a little over $170 \%$ in 2019 (Figure 7).

As bad as this forecast was for Venezuela's sovereign debt dynamics, the reality was even worse. By 2019, debtGDP had actually soared to over $230 \%$ of GDP. The extent of the deterioration is both dramatic and was not widely expected in magnitude. In its latest forecasts, the IMF essentially threw in the towel, and did not even try to "nowcast" what debt-GDP was last year. Comparing the 2019 figures, the IMF was again over-optimistic here, under-estimating the debt-GDP ratio by just over 60 ppts.

\subsection{Barbados in 2018}

The final notable sovereign default considered here is that of Barbados in 2018. The Caribbean nation faced mounting fiscal and external imbalances in the wake off the global financial crisis, while at the same time resisting calls to abandon the country's longstanding currency peg to the US dollar. By 2018 the debt burden had more than doubled compared with 2008 , exceeding $100 \%$ of GDP.

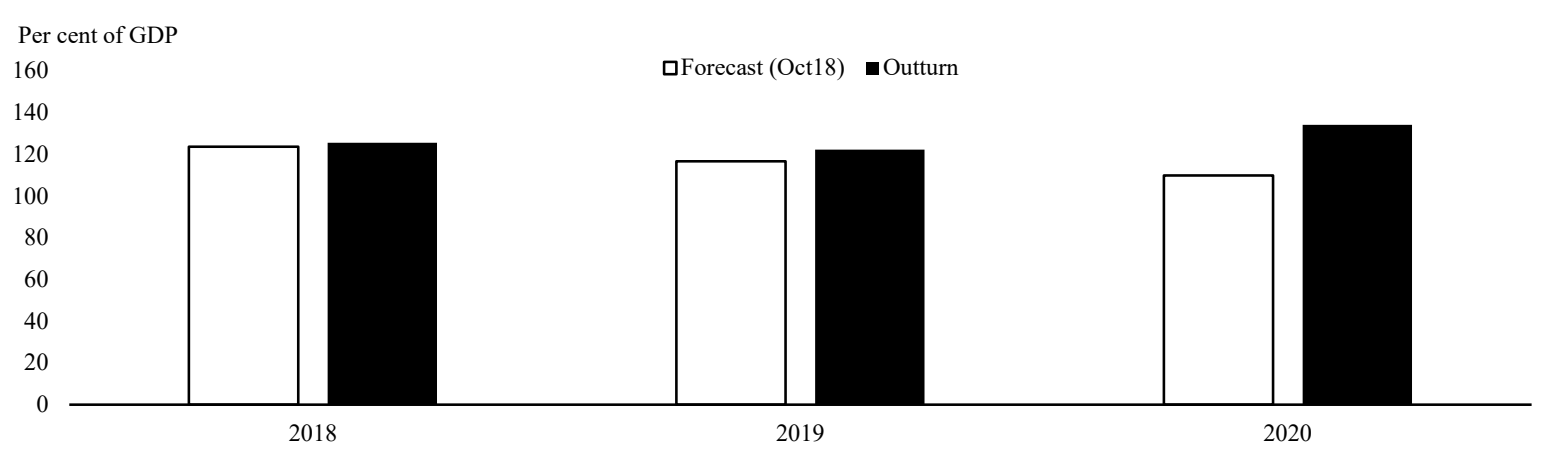

Figure 8. Barbadian government debt-GDP forecast and outturns

Source: IMF and author's calculations. 2020 outturn reflects IMF's latest forecast. 
These pressures led the newly elected government to announce in June 2018 that it was suspending interest payments on external debt, while asking domestic creditors to roll over maturing principal. It formally entered default on 19 June 2018 when the grace period for scheduled interest payments expired. Subsequent to that, the government spent 18 months negotiating with creditors, before agreeing a restructuring that finalised in December 2019 with full creditor participation.

Given the timing of the default in June 2018, the subsequent forecast from the IMF was published in October 2018. As such, the gap here between the default and most recent outturns is relatively small, at just two calendar years. But even here the pattern seen for previous defaults is already becoming apparent.

In particular, in its October 2018 forecasts the IMF predicted that Barbadian debt-GDP would fall over the two years following the default, to stand at just under $110 \%$ of GDP. In fact, while debt-GDP fell slightly in 2019, last year it actually increased to $134 \%$, almost 25 ppts higher than forecast (Figure 8). Yet again, the IMF forecast immediately following the sovereign default was over-optimistic.

\section{Discussion and a Modest Proposal}

Sovereign defaults are difficult and complicated, and often rely on crucial assumptions about future debt sustainability. From looking at the sovereign defaults outlined above, it is evident that the IMF has systematically exhibited over-optimism in its assessments of debt dynamics. Across the six major sovereign defaults covered, the average forecast error in debt-GDP for the IMF was just over 30 percentage points (adjusting for Ukraine's data revisions). While the sample size is obviously small, the consistency of the direction of forecast errors represents a clear pattern despite the notable idiosyncrasies of the different sovereign defaults as set out above.

Given the critical role of DSA in any sovereign restructuring process, such a large forecast error can only have a significant impact on the appropriateness of those restructurings. In particular, the over-optimism evident in forecasts is entirely consistent with a significant share of defaulting sovereigns then defaulting again a second time. It is also consistent with only a gradual pace of improvement in credit ratings post-default.

This leads naturally onto a modest proposal arising from this analysis, which is both timely relevant given likely sovereign defaults over the medium term. In particular, future sovereign debt restructurings should be based on more pessimistic forecasts for debt dynamics. The IMF or other body conducting the sustainability analysis should deliberately 'aim off' their best guess, on the basis of past forecast errors, and focus on a more pessimistic or downside scenario. In principle, this would be more akin to the types of stress test analyses often run by central banks (and other policymaking groups) for financial institutions. In practice, there is simply a clear need to use more pessimistic assumptions in order to adjust for clear bias in past forecasts. This applies equally to any DSA associated with the DSSI or its successor initiatives; but also to restructurings more generally.

Given that more pessimistic assumptions about debt dynamics will naturally make it more difficult for sovereigns to been seen to achieve debt sustainability after a default, the obvious corollary here is that future sovereign defaults should impose higher losses on all creditors. At the moment, there is little sign that losses given defaults (LGDs) for sovereigns are significantly different from those from corporates. But given the pervasive nature of sovereign defaults, and the negative effects and externalities that can arise, the social costs of sovereign defaults will be higher than those of corporate defaults. In effect, imposing larger losses on sovereign creditors would be a way of distributing some of those negative impacts.

Clearly this proposal will meet significant resistance from creditors, who will want to continue to limit the losses they face from any sovereign restructuring. But the simple fact is that it is untenable to continue to base any analysis of public debt sustainability on clearly biased forecasts. Furthermore, if this modest proposal were followed then it should, other things being equal, reduce the risk of re-default and enable defaulting governments to thereafter regain their creditworthiness more swiftly. Over the long run, that is likely to be more desirable both for defaulting sovereigns and their creditors alike.

\section{References}

Barkbu, B., Eichengreen, B., \& Mody, A. (2012). Financial crises and the multilateral response: What the historical record shows. Journal of International Economics, 88, 422-435. https://doi.org/10.1016/j.jinteco. 2012.02.006

Barr, D., Bush, O., \& Pienkowski, A. (2014). GDP-linked bonds and sovereign default. Bank of England Working Paper Series No. 484. https://doi.org/10.2139/ssrn.2388768

Brooke, M., Mendes, R., Pienkowski, A., \& Santor, E. (2013). Sovereign default and state-contingent debt. Bank of England Financial Stability Paper No. 27. 
Moody's (2012). Investor Losses in Modern-Era Sovereign Bond Restructurings. Retrieved from https://www.moodys.com/researchdocumentcontentpage.aspx?docid=PBC_144129

Moody's (2021). Rating Symbols and Definitions. Retrieved from: https://www.moodys.com/researchdocument contentpage.aspx?docid=PBC_79004

Shiller, R. (1998). Macro Markets: Creating Institutions for Managing Society's Largest Economic Risks. Oxford, United Kingdom: Oxford University Press. https://doi.org/10.1093/0198294182.001.0001

Sturzenegger, F., \& Zettelmeyer, J. (2006). Debt Defaults and Lessons from a Decade of Crises. Cambridge, Massachusetts: MIT Press. https://doi.org/10.7551/mitpress/2295.001.0001

\section{Copyrights}

Copyright for this article is retained by the author(s), with first publication rights granted to the journal.

This is an open-access article distributed under the terms and conditions of the Creative Commons Attribution license (http://creativecommons.org/licenses/by/4.0/). 